\title{
Plasma exchange in critically ill COVID-19 patients
}

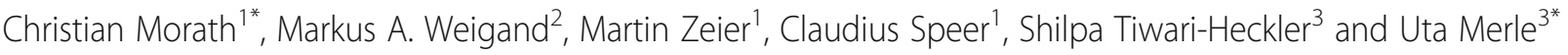

The spectrum of coronavirus disease 2019 (COVID-19) ranges from asymptomatic infection to respiratory failure and death of patients [1]. Severely affected patients may develop a cytokine storm-like clinical syndrome with multi-organ failure and a mortality rate of up to $90 \%$ [2]. Recently, it has been suggested that plasma exchange (PE) may positively influence this unfavorable course [3].

Here we report on five COVID-19 patients with a median age of 67 years who were admitted to the medical intensive care unit of Heidelberg University Hospital due to respiratory failure. Patients who had received at least one $\mathrm{PE}$ until May 15, 2020, were considered for analysis with clinical follow-up until June 15, 2020. Prophylactic antibiotic (piperacillin/ tazobactam), antimycotic (caspofungin), and antiviral/immunomodulatory therapy (hydroxychloroquine or maraviroc) was initiated in all patients upon admission according to center practice. Additional treatments that were administered in some distance to $\mathrm{PE}$ are given in Table 1. During the course of the disease, patients developed vasopressor-dependent circulatory shock and/or persistent refractory fever $\left(>40.5^{\circ} \mathrm{C}\right)$ together with increased interleukin 6 levels compatible with the cytokine storm-like clinical syndrome. In addition, all patients had multi-organ failure with acute respiratory distress syndrome (ARDS, 4 severe, 1 moderate) and acute kidney injury of at least KDIGO stage 2. A single PE with a median of $3.39 \mathrm{~L}$ of fresh frozen plasma was initiated in all patients followed by one additional treatment in patients 1,3 , and 5 . During the $\mathrm{PE}$, striking reduction of inflammatory markers C-reactive protein $(-47 \%, P=0.0078)$ and interleukin $6(-74 \%, P=0.0078)$, as well as significant reduction of ferritin $(-49 \%, P=0.0078)$, LDH $(-41 \%, P=0.0078)$, and D-dimer $(-47 \%, P=0.016)$ were observed (Fig. 1a-e). Due to circulatory shock, four patients received vasopressor treatment at the start of the PE that could be substantially reduced during treatment $(-71 \%, P=0.031$, Fig. 1h). Biochemical and clinical improvement continued over the following days together with an increase in the oxygenation index in 4 out of 5 patients (Fig. 1i). These improvements were achieved with only 1 to 2 $\mathrm{PE}$, which might be a possible indication of a direct pathophysiological influence of PE on the COVID19-associated cytokine storm-like clinical syndrome. Three of the 5 most critically ill patients are alive, while a 71-year-old male and a 76-year-old female

\footnotetext{
* Correspondence: Christian.Morath@med.uni-heidelberg.de;

Uta.Merle@med.uni-heidelberg.de

'Department of Nephrology, Heidelberg University Hospital, Heidelberg, Germany

${ }^{3}$ Department of Internal Medicine IV, Heidelberg University Hospital, Heidelberg, Germany

Full list of author information is available at the end of the article
} 

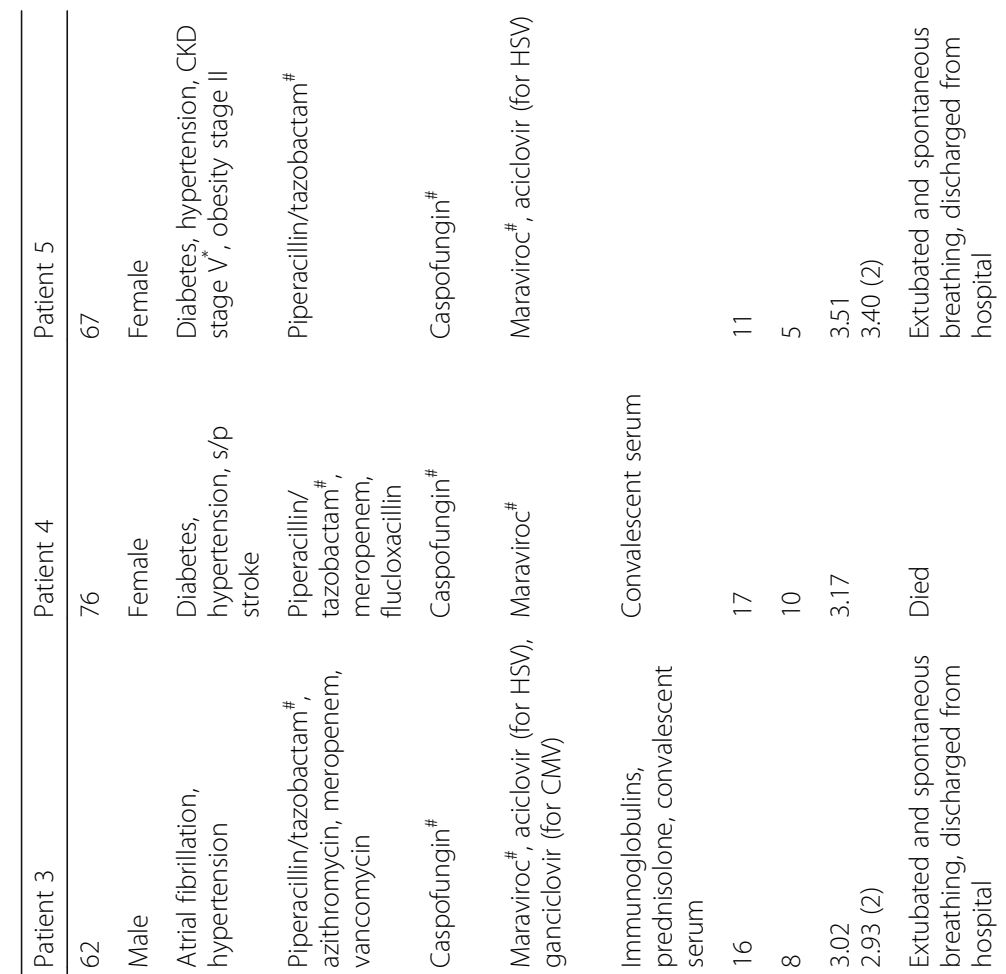

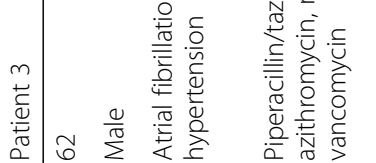
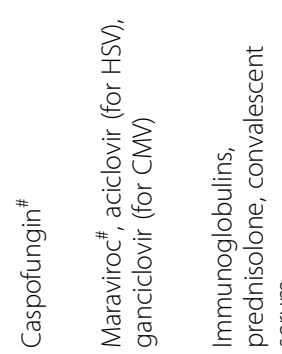

$\infty$ m
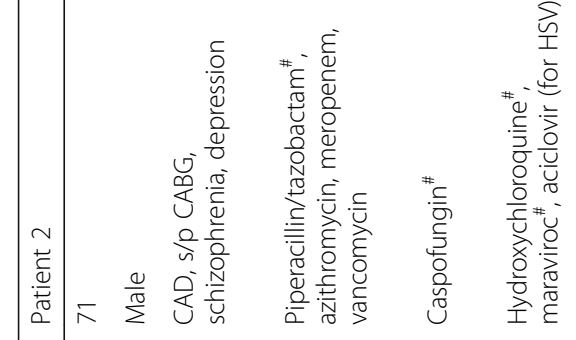

논

$\frac{0}{\frac{0}{3}}$

은 는

종
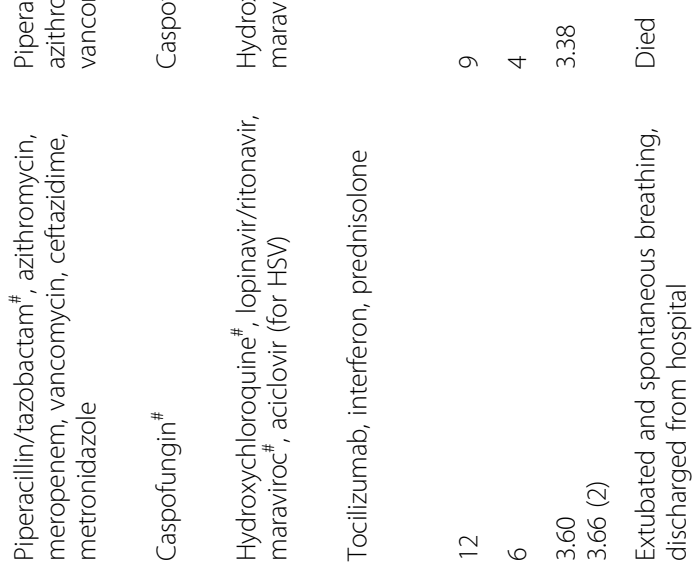

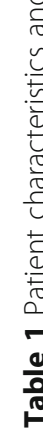
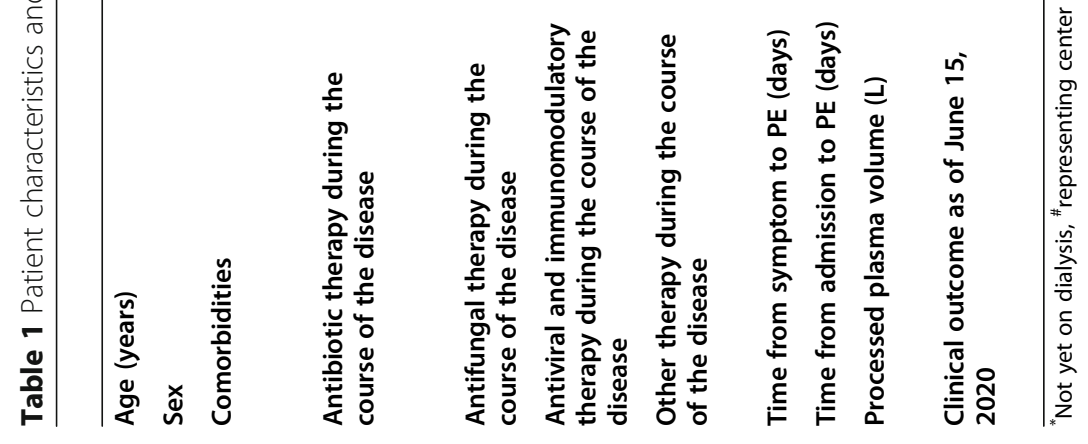

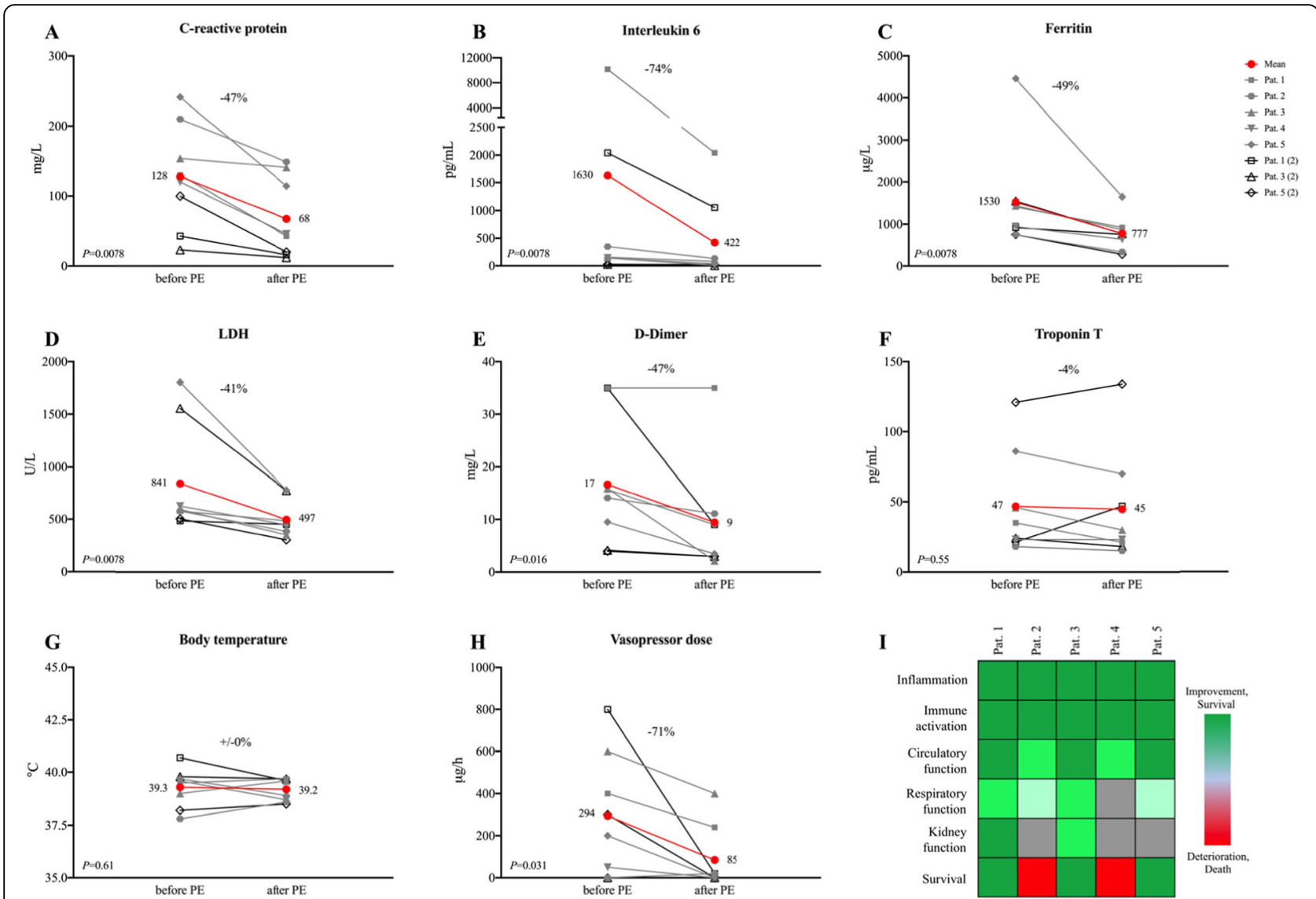

Fig. 1 Changes of biochemical (a-f) and clinical ( $\mathbf{g}-\mathbf{i})$ parameters during plasma exchange. $\mathbf{a}-\mathbf{f}$ The first value after plasma exchange (PE) is compared to the last value before PE. $\mathbf{g}-\mathbf{h}$ Mean values for the $24 \mathrm{~h}$ after compared to the $24 \mathrm{~h}$ before PE are given. Wilcoxon matched-pairs signed rank test was used for statistical analysis

patient died after the therapy was limited due to persistent severe ARDS.

It has been suggested that a cytokine storm-like clinical syndrome may be responsible for a significant proportion of COVID-19-associated patient deaths [4]. PE improved inflammation, microcirculatory clot formation, and hypotension, thereby improving clinical outcomes. Further studies to test whether (repeated) PE can alter the course of critically ill COVID-19 patients are clearly indicated.

\section{Acknowledgements}

Not applicable.

\section{Authors' contributions}

CM, MAW, MZ, and UM designed the work, CS, and STH collected and analyzed the data, CM and UM interpreted the data, CM, MAW, MZ, and UM drafted the work or substantively revised it, and all authors read and approved the final manuscript.

\section{Funding}

There was no funding for the study.

\section{Availability of data and materials}

All data generated or analyzed during this study are included in this published article.
Ethics approval and consent to participate

Biochemical and clinical parameters were collected under the ethics vote S148/2020 of the Ethics Committee of Heidelberg University, and informed consent was retrieved from legal representatives of the patients.

\section{Consent for publication}

Informed consent was retrieved from legal representatives of the patients.

\section{Competing interests}

The authors declare that they have no competing interests.

\section{Author details}

${ }^{1}$ Department of Nephrology, Heidelberg University Hospital, Heidelberg, Germany. 'Department of Anesthesiology, Heidelberg University Hospital, Heidelberg, Germany. ${ }^{3}$ Department of Internal Medicine IV, Heidelberg University Hospital, Heidelberg, Germany.

Received: 1 July 2020 Accepted: 12 July 2020

Published online: 04 August 2020

\section{References}

1. Zhou F, Yu T, Du R, et al. Clinical course and risk factors for mortality of adult inpatients with COVID-19 in Wuhan, China: a retrospective cohort study. Lancet. 2020;395(10229):1054-62.

2. Wang D, Yin Y, Hu C, et al. Clinical course and outcome of 107 patients infected with the novel coronavirus, SARS-CoV-2, discharged from two hospitals in Wuhan, China. Crit Care. 2020;24(1):188.

3. Keith P, Day M, Perkins L, Moyer L, Hewitt K, Wells A. A novel treatment approach to the novel coronavirus: an argument for the use 
of therapeutic plasma exchange for fulminant COVID-19. Crit Care. 2020; 24(1):128.

4. Moore JB, June CH. Cytokine release syndrome in severe COVID-19. Science. 2020;368(6490):473-4.

\section{Publisher's Note}

Springer Nature remains neutral with regard to jurisdictional claims in published maps and institutional affiliations.

Ready to submit your research? Choose BMC and benefit from:

- fast, convenient online submission

- thorough peer review by experienced researchers in your field

- rapid publication on acceptance

- support for research data, including large and complex data types

- gold Open Access which fosters wider collaboration and increased citations

- maximum visibility for your research: over $100 \mathrm{M}$ website views per year

At $\mathrm{BMC}$, research is always in progress.

Learn more biomedcentral.com/submissions 